DOI 10.37882/2223-2974.2020.09.10

\title{
К ВОПРОСУ О ПРОБЛЕМАХ ЗАЩИТЫ ДАВНОСТНОГО ВЛАДЕНИЯ НЕДВИЖИМОГО ИМУЩЕСТВА
}

\section{TO THE QUESTION ABOUT PROBLEMS OF PROTECTING LONG-RANGE PROPERTY OF REAL ESTATE PROPERTY}

\author{
A. Gudkov \\ A. Krasilschikov \\ V. Mishchenko
}

Summary: In this article, the authors investigated problematic issues in the use of such a tool for protecting property rights to real estate, as acquisitive prescription. Analyzed and reveals the essence of legal practice affecting the specifics of using this method of protecting the rights of real estate owners in courts, an emphasis is placed on the gaps in the legislation regarding the use of this method of protection. At the same time, it is emphasized that the legal regulation of this issue is not complete from the point of view of taking into account various situations caused by both objective reasons and circumstances, and the deliberate actions of a party evading the conclusion of contracts for the transfer of disputed real estate initially.

Keywords: civil law, acquisitive prescription, real estate, judicial practice, legal regulation.
Гудков Анатолий Иванович

К.ю.н., дочент, Владимирский юридический институт ФСИН Росcuu,

gudkovaniv@yandex.ru

Красильщиков Анатолий Владимирович

К.ю.н., дочент, Владимирский юридический институт ФСИН России

krasilschikov@inbox.ru

Мищенко Вячеслав Иванович

К.ф.н., дочент, Владимирский юридический институт ФСИН России,

vyacheslav-mischenko@mail.ru

Аннотация: В настоящей статье авторами исследованы проблемные вопросы в сфере использования такого инструмента защиты прав собственности на недвижимое имущество, как приобретательная давность. Анализируется и раскрывается сущность правовой практики, затрагивающей специфику использования указанного способа защиты прав владельцев недвижимости в судах, делается акцент на пробелы, имеющиеся в законодательстве в части использования указанного способа защиты. Одновременно с этим подчеркивается, что правовое регулирование данного вопроса не является полным с точки зрения учета различных ситуаций, вызванных как объективными причинами и обстоятельствами, так и сознательными действиями стороны, уклоняющейся от заключения договоров на передачу спорного недвижимого имущества изначально.

Ключевые слова: гражданское законодательство, приобретательная давность, недвижимое имущество, судебная практика, правовое регулирование.
$\mathrm{B}$ настоящее время приобретательная давность является не только одним из способов защиты гражданских прав, но и рассматривается законодателем как способ возврата имущества в гражданский оборот, поскольку в какой-то момент перехода от плановой экономики к рыночной некоторая часть недвижимого имущества, в том числе и находящаяся в пользовании у граждан, утратила свою правовую идентификацию.

К примеру, частыми случаями такой неопределенности стали инциденты с несоблюдением формы договора о передаче недвижимого имущества в собственность (договора купли-продажи недвижимости), что, как следствие, стало причиной появления административных барьеров в регистрации указанных в данных договорах объектах недвижимости, последовательно относя их состояние к спорным, а также, исключая между сторонами, заключившими такое соглашение, наличие каких-либо обязательств.

В частности, одним из проблемных направлений в данном вопросе служит наличие так называемого порока формы соглашения, которое необходимо заключать с целью последующей регистрации любого недвижимого имущества.

Так, в части разъяснений, изложенных в постановлении «О некоторых вопросах, возникающих в судебной практике при разрешении споров, связанных с защитой права собственности и других вещных прав» [4, п. 15] высшей судебной инстанцией нашей страны дано вполне конкретное указание на то, что основание приобретательной давности не может быть использовано в случае, если спорное имущество было передано на основании договора, к которым судам необходимо относить любой договор, определяющий законное владение спорным недвижимым имуществом: договор аренды, хранения, безвозмездного пользования, и т.п.

Вместе с тем, на практике и в теоретическом русле рассматриваемого вопроса возникает немало обоснованных возражений относительно его урегулирован- 
ности, так как законодателем не в полной мере изучен вариант развития событий, при которых передача спорного имущества состоялась без заключения какого-либо соглашения, однако в последствии, одна из сторон уклоняется от его заключения, либо сами условия не позволяют сделать этого по объективным причинам.

Как справедливо отмечает Н.А. Абляпитова, в судебной практике, на указанном основании, сформировалась порочная система, имеющая под собой круговой эффект [9, с.20]. В частности, суды, отказывая в признании права собственности на спорное имущество на основании приобретательной давности ссылаются на общие положения гражданского законодательства в части заключения сделок на приобретение права собственности.

Среди используемых оснований для отказа признания права собственности на основании приобретательной давности отмечается, что, если соглашение не заключалось, следовательно, установить переход права собственности на указанное имущество нельзя. При этом следует вывод: в этом случае признавать право собственности за гражданином, даже если он владеет им добросовестно, непрерывно и долго, нет никаких оснований.

Например, в Апелляционном определении СанктПетербургского городского суда от 20.05.2019 указано, что сторонами не заключалось соглашение в письменной форме о купле-продаже, при этом представленная сторонами переписка не может служить достаточным свидетельством его заключения, а только является косвенным доказательством о выражении намерений в желании его заключить в будущем. При таком положении дел, суд не имеет права признавать факт соглашения между сторонами, и в свою очередь, полагает, что данные отношения носят бездоговорной характер, а, следовательно, признавать передачу имущества в законное владение в данном случае будет не верным. Такого же мнения придерживаются и другие судебные инстанции, доказательством чему служат решения, выносимые в спорах по аналогичным обстоятельствам (Апелляционное определение Санкт-Петербургского городского суда от 15.02.2017 № 33-3314/2017 [5] по делу № 2-1359/2016 [6], Апелляционное определение Свердловского областного суда от 03.09.2015 [7]).

Другим примером такого положения дел служит ситуация, когда заключенный договор социального найма, дающий возможность бенефициарию приобретение права собственности на конкретный объект недвижимости через процедуру приватизации, был заключен учреждением или предприятием, впоследствии утратившим свой социально-правовой статус, при условии, что его правопреемник оспаривает данный договор, указывая на неправомерность его заключения.
Так, в одном из судов Ивановской области было рассмотрено исковое заявление, где гражданка Н. требовала от суда признания за ней права собственности на недвижимое имущество в виде жилого дома, которым она владела непрерывно более 20 лет [8, с.20].

В то же время, истец, сопровождая свои требования вполне конкретными обстоятельствами, подтверждающими не только факт беспрерывного, добросовестного и открытого владения указанным имуществом на протяжении, предусмотренным ст.234 Гражданского Кодекса РФ [2] срока, но и указывая на то, что данное недвижимое имущество было передано ей на основании заключенного соглашения, указала, что обратилась в суд по основаниям приобретательной давности, поскольку при заключении договора социального найма, определяющего её право владения и пользования указанным имуществом, не был соблюден порядок, установленный законом, договор социального найма был заключен лицом, не обладающим таким правом в соответствии со ст. 60 Жилищного Кодекса РФ [3]. Помимо прочего, истец привела доводы, что владеет имуществом уже долгое время, и, несмотря на несоблюдение требований закона, которые были нарушены по вине прежде всего противной стороны, а также отсутствие сведений о регистрации предмета иска в едином реестре учета недвижимого имущества, добросовестно несла бремя содержания данного имущества, а следовательно имеет право на признание его своей собственностью. Суд удовлетворил требования истца, указав при этом, что приобретательная давность - это один способов легитимного возврата имущества в гражданский оборот, а также удовлетворения интересов граждан в части притязаний на материальные блага, приобретение которых является социально обусловленными и относящимися к одним из основных прав, гарантированных ст.35 Конституции РФ [1].

Исходя из вышеизложенного, можно сделать вывод о том, что ситуация с признанием права собственности при необходимости использования основания приобретательной давности проработана законодателем достаточно полно. Между тем, на наш взгляд, необходимо внести коррективы в действующее законодательство, приравняв действия, направленные на передачу во владение и пользование недвижимого имущества, к действиям, преследующим цель на передачу права собственности, одновременно признавая их добросовестными и соответственно законными, при условии, что такие действия основаны на безоговорочном волеизъявлении, а также, если такие действия впоследствии могут лечь в основу использования рассматриваемого основания - приобретательной давности. Такой подход позволит избежать вариантов с неправомерным завладением имущества, а также устранит противоречия, возникающие в судах, при том условии, когда собственник спорного имущества отсутствует. 


\section{ЛИТЕРАТУРА}

1. Конституция Российской Федерации (принята всенародным голосованием 12.12 .1993 с изменениями, одобренными в ходе общероссийского голосования 01.07.2020) // Официальный текст Конституции РФ С внесенными поправками от 14.03.2020 опубликован на Официальном интернет-портале правовой информации http://www.pravo.gov.ru, 04.07.2020.

2. Гражданский кодекс Российской Федерации (часть первая) от 30.11.1994 N 51-Ф3 (ред. от 16.12.2019, с изм. от 12.05.2020). // Собрание законодательства РФ. 05.12.1994. N 32. ст. 3301.

3. Жилищный кодекс Российской Федерации от 29.12.2004 N 188-Ф3 (ред. от 25.05.2020) // Собрание законодательства РФ. 03.01.2005. N 1 (часть 1). ст. 14.

4. Постановление Пленума Верховного Суда РФ N 10, Пленума ВАС РФ N 22 от 29.04.2010 «0 некоторых вопросах, возникающих в судебной практике при разрешении споров, связанных с защитой права собственности и других вещных прав» (ред. от 23.06.2015) // Российская газета. N 109. 21.05.2010.

5. Апелляционное определение Санкт-Петербургского городского суда от 20.05.2019 № 33-6672/2019 по делу № 2- 2262/2018 [Электронный ресурс]. Режим доступа: URL: http://www.consultant.ru (дата обращения: 02.08.2020).

6. Апелляционное определение Санкт-Петербургского городского суда от 15.02.2017 № 33-3314/2017 по делу № 2- 1359/2016 [Электронный ресурс] // Режим доступа: URL: http://www.consultant.ru (дата обращения: 02.08.2020).

7. Апелляционное определение Свердловского областного суда от 03.09.2015 по делу № 33-12967/2015 [Электронный ресурс]. - Режим доступа: URL: http:// www.consultant.ru (дата обращения: 02.08.2020).

8. Обзор деятельности Вичугского городского суда за 2019 год. [Электронный ресурс]. Сайт Вичугского городского суда Ивановской области. // Доступ: httр:// vichugsky.iwn.sudrf.ru/modules.php?name=docum_sud\&id=356 (дата обращения: 02.08.2020).

9. Аблятипова Н.А. Особенности применения правил о сроках приобретательной давности в российской правовой системе: на примере судебной практике республики Крым. Нотариус. 2020. № 4. С. 19-22.

(с Гудков Анатолий Иванович (gudkovaniv@yandex.ru), Красильщиков Анатолий Владимирович (krasilschikov@inbox.ru), Мищенко Вячеслав Иванович (vyacheslav-mischenko@mail.ru).

Журнал «Современная наука: актуальные проблемы теории и практики»

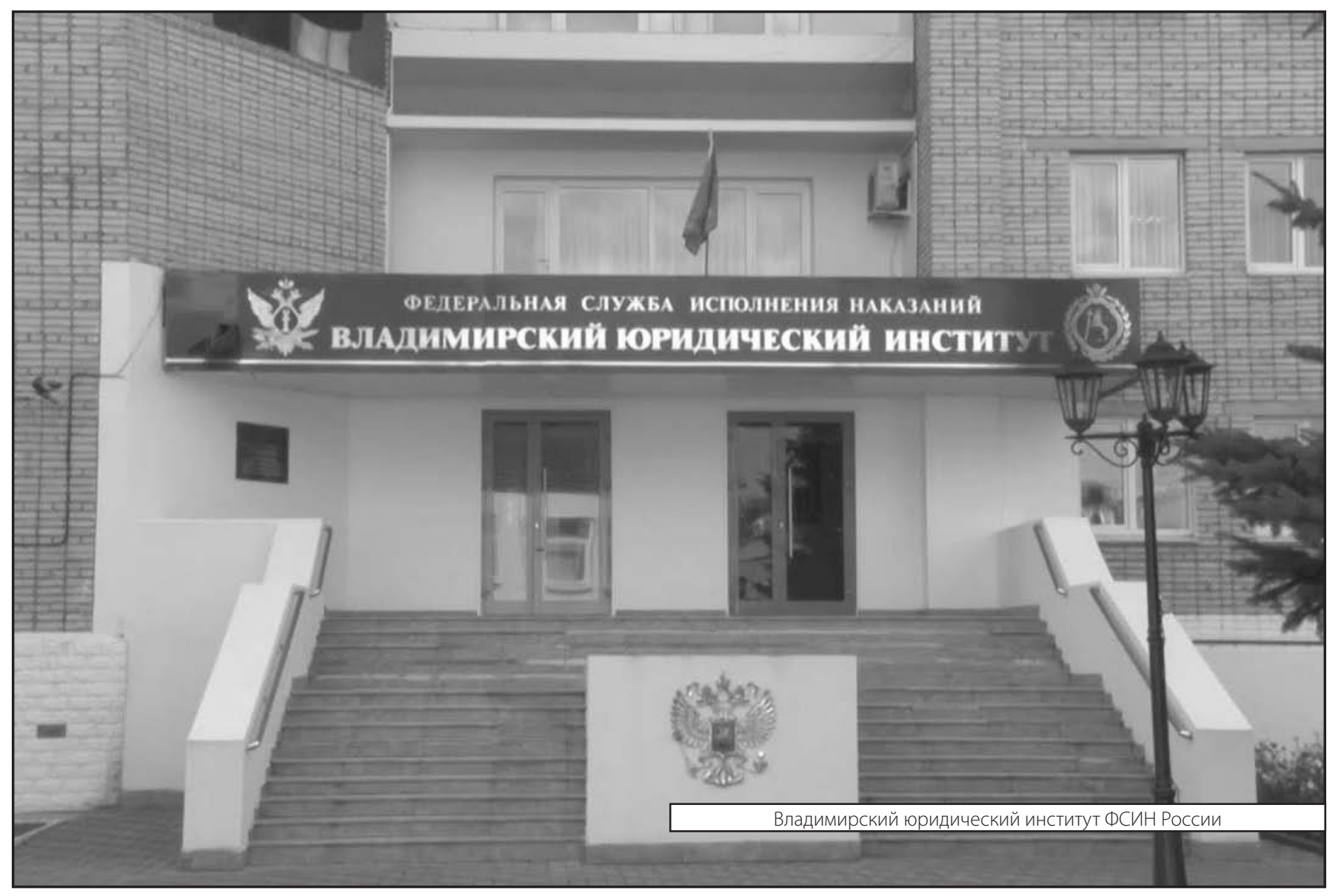

